\title{
Interaction of Synthetic Opioid Metenkephalin Peptide Analogs, Lilly 127623 and FK 33-824 with Indole Hallucinogens: Antagonism of N,N-Dimethyltryptamine- and LSD-Induced Disruption of Food-Rewarded Bar Pressing Behavior in the Rat
}

\author{
Diane M. Ruffing ${ }^{1}$ and Edward F. Domino ${ }^{2}$ \\ ${ }^{1}$ Division of Pharmacology, Lafayette Clinic, 951 E. Lafayette, Detroit, MI 48207, USA \\ ${ }^{2}$ University of Michigan, Department of Pharmacology, Ann Arbor, MI 48109, USA
}

\begin{abstract}
The selected opioid metenkephalin synthetic peptide analogs Lilly (LY) 127623 and FK 33-824 were tested for behavioral dose effects and potential interaction with N,Ndimethyltryptamine (DMT) and lysergic acid diethylamide25 (LSD) in adult male Holtzman rats trained on a positive reinforcement fixed-ratio 4 (FR-4) behavioral bar pressing schedule, i.e., a reward of ' $0.01 \mathrm{ml}$ sugar-sweetened evaporated milk was earned on every fourth bar press. DMT $(3.2 \mathrm{mg} / \mathrm{kg})$ and LSD $(0.1 \mathrm{mg} / \mathrm{kg})$, administered IP following a $0.9 \% \mathrm{NaCl} 15-20$-min control pretreatment, disrupted established food-rewarded FR-4 bar pressing in a consistent and reproducible manner. Animals pretreated IP with predetermined behaviorally noneffective doses of LY 127623 $(0.01-0.32 \mathrm{mg} / \mathrm{kg})$ and FK $33-824(0.001-0.01 \mathrm{mg} / \mathrm{kg}) 15-$ 20 min prior to receiving DMT demonstrated significant antagonism to DMT-induced disruption of FR-4 bar pressing, while doses of $0.10-0.32 \mathrm{mg} / \mathrm{kg}$ LY 127623 and $0.00032-0.0032 \mathrm{mg} / \mathrm{kg}$ FK $33-824$ significantly antagonized LSD-induced behavioral effects.
\end{abstract}

Key words: Opioids - Metenkephalin - Peptides - LY 127623 - FK 33-824 - DMT - LSD - Antagonism Operant behavior

A therapeutic or pathogenic involvement of opioids in psychoses has been indicated by numerous biological and pharmacological investigations (Barchas et al. 1980; van Praag and Verhoeven 1980; deWied 1980; Marx 1981; Anokhina 1982). These studies, coupled with the recent evidence of multiple opiate receptors and endogenous opioidlike peptides, have stimulated interest in the potential behavioral and therapeutic applications of endogenous endorphins, enkephalins, and their related synthetic analogs (Gesellchen and Zimmermann 1981; Martin 1981; Van Ree and deWied 1981; Szara 1982).

In recent investigations we reported that the opioid antagonists naloxone and naltrexone potentiated induced disruptive effects of $\mathrm{N}, \mathrm{N}$-dimethyltryptamine (DMT) and LSD on food-rewarded fixed-ratio (FR-4) behavior in the rat, whereas low doses of the opioid agonists morphine and methadone antagonized the behavioral effects of DMT and LSD, while larger doses selectively potentiated only the effects of LSD (Ruffing and Domino 1979, 1981). The purpose of the present study was to determine possible

Offprint requests to: E. F. Domino interactions of selected metenkephalin synthetic peptide analogs with DMT and LSD using rodents in an operant FR-4 behavioral paradigm.

\section{Materials and Methods}

Adult male Holtzman rats (at least 90 days of age) were housed separately in a constant temperature- and humiditycontrolled environment. Animals were maintained at approximately $70 \%$ of their expected free-feeding weight.

Procedures. The methods for establishing stable foodrewarded FR-4 bar pressing and experimental design parameters have been described in detail (Ruffing and Domino 1981). In brief, rats were trained to bar press daily for sessions of 60-min duration on a FR schedule to receive a reward of $0.01 \mathrm{ml}$ sweetened evaporated milk solution as positive reinforcement on every fourth bar press. Operant behavioral experiments were performed in an isolated, darkened room using Lehigh Valley Electronics rodent operant test chambers (model 143-21) and Gerbrand cumulative recorders.

Subsequent to established, stable FR-4 bar pressing, rats were randomly scheduled to assigned drug and dose groups $(N=6-12)$ and daily bar pressing sessions of 60-min duration for at least 5 days prior to injections. Each animal served as its own control to compare hallucinogen-induced effects with and without assigned pretreatment drugs, with an intervening minimum 7-day drug-free interval between scheduled injections. Prior to the assigned hallucinogen injection (3.2 mg/kg DMT or $0.1 \mathrm{mg} / \mathrm{kg}$ LSD IP), control groups were pretreated $(15-20 \mathrm{~min})$ with $0.9 \% \mathrm{NaCl}$ (IP), whereas drugpretreated groups received a predetermined behaviorally noneffective dose of LY $127623(0.0032-0.32 \mathrm{mg} / \mathrm{kg}$ IP) or FK $33-824(0.0001-0.01 \mathrm{mg} / \mathrm{kg}$ IP) as pretreatment $15-$ 20 min prior to DMT or LSD. The pretreatment drug doses described demonstrated no effect on bar pressing for 120-min periods, as predetermined in pilot studies (Domino and Ruffing 1982). Drugs were administered IP and dosages refer to free base content.

Data Analysis. The duration of drug effect was determined from the length of the horizontal line generated by the cumulative recorder illustrating the onset, duration, and cessation of drug effects or disruption of bar pressing behavior. Two-tailed Student's $t$-test paired comparisons, calculated according to Snedecor and Cochran (1967), were used to analyze the statistical significance of drug effects for control and corresponding drug-pretreated groups, i.e., antagonism, potentiation, or no effect on the behavioral FR-4 
disruptive effects characteristically induced by DMT and LSD.

Drugs. DMT was obtained from Sigma (St. Louis, MO, USA) and solutions were prepared by dissolving the free base in $1 \mathrm{~N}$ $\mathrm{HCl}$, adding $0.9 \% \mathrm{NaCl}$, and titrating the acidity with $0.1 \mathrm{~N}$ $\mathrm{NaOH}$ to adjust $\mathrm{pH}$ to $4.5-5.0$. LSD-25 (Delysid) was obtained from the National Institute on Drug Abuse and was administered in $0.9 \% \mathrm{NaCl}$. Lilly (LY) 127623 (Metkephamid) and FK 33-824 log doses were administered in $0.9 \%$ $\mathrm{NaCl}$, and supplied courtesy of Dr. R. Frederickson (Lilly Research Laboratories, Eli Lilly and Company, Indianapolis, IN, USA) and Drs. Graffenried and del Pozo (Department of Experimental Therapeutics, Biololgical and Medical Research Division, Sandoz Limited, Basel, Switzerland), respectively.

\section{Results}

Characteristic gross behavioral effects of DMT and LSD were evident $2-5 \mathrm{~min}$ following IP injections and consisted of lying quietly with eyes open in an excessively flattened position for prolonged intervals, periodic display of Straub tail with or without locomotor or body movements, circling or reverse crawling in a flattened position, splayed legs or extension of the hind limbs, frequent stereotypic and repetitive head or body movements, sustained periods of arching, and disinterest in food or bar pressing. The gross behavioral effects of DMT $(3.2 \mathrm{mg} / \mathrm{kg})$ and LSD $(0.1 \mathrm{mg} / \mathrm{kg})$ were reproducible and commensurable with the duration of induced disruption of food-rewarded FR-4 bar pressing behavior.

In the LY 127623 and FK 33-824 pretreatment groups, gross behavioral effects following DMT or LSD were usually minimal or absent, although atypical gross behavioral effects were noted in several animals $(N=4)$, i.e., mild to moderate increase in behavioral locomotor activity involving excessive exploring, grooming, and periodic interest in the bar, which may or may not have resulted in pressing for food reinforcement. Following the cessation of drug effects, rats would appear normal, groom briefly, and abruptly start and continue bar pressing at preinjection response rates. Typically, cumulative bar pressing records of rats trained on foodrewarded FR-4 schedules show constant high rates of response with momentary postreinforcement pausing (Ferster and Skinner 1957; Wenger 1980).

The synthetic metenkephalin peptide pretreatment groups showed that some doses of LY $127623(0.01-0.32 \mathrm{mg} / \mathrm{kg})$ and FK $33-824(0.00032-0.01 \mathrm{mg} / \mathrm{kg})$ significantly antagonized the disruption of FR-4 bar pressing induced by DMT and LSD. As illustrated in Fig. 1, pretreatment doses of LY $127623(0.01-0.32 \mathrm{mg} / \mathrm{kg})$ and FK 33-824 (0.001-0.01 mg/ $\mathrm{kg}$ ) significantly antagonized DMT-induced disruption of FR-4 bar pressing, while significant antagonism to the LSD-

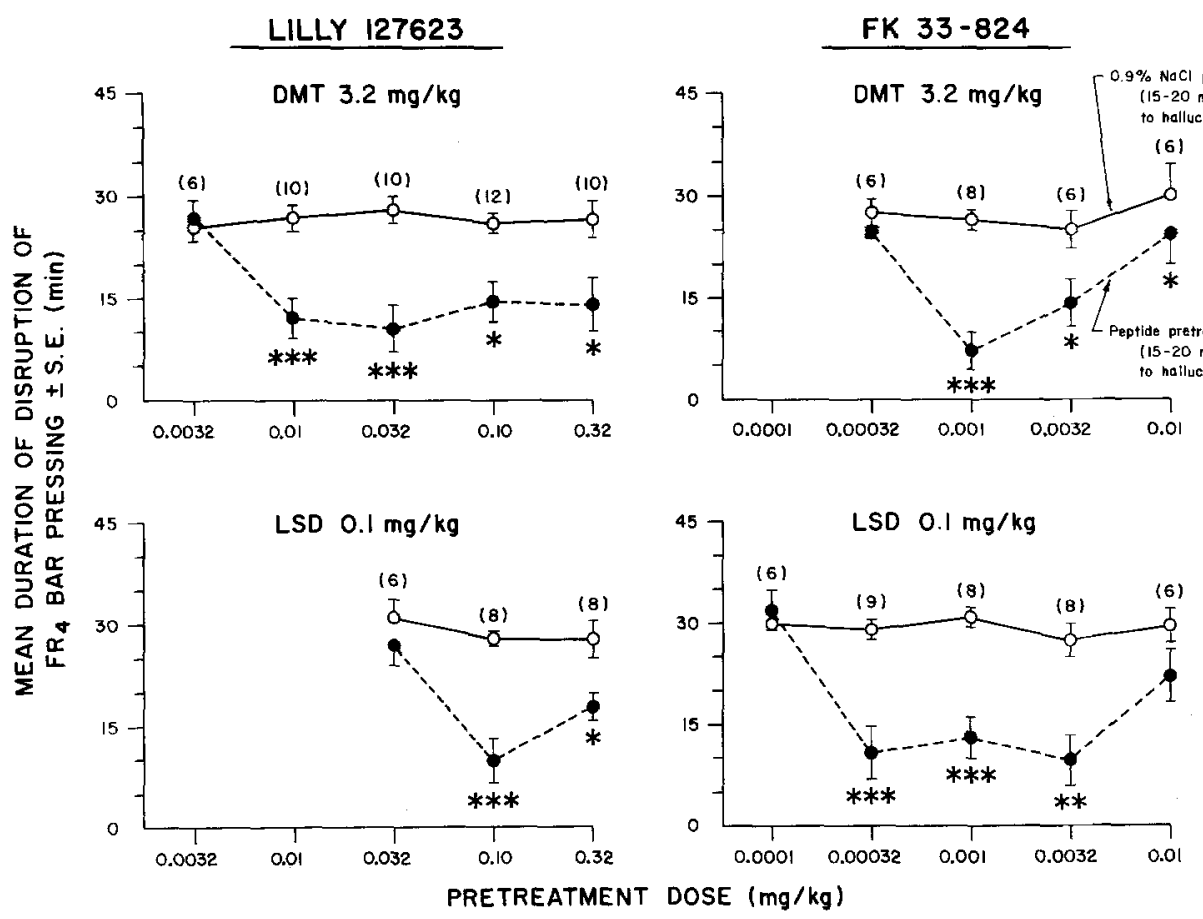

Fig. 1. Dose-dependent effects of Lilly 127623 and FK 33-824 pretreatment on the duration of DMT-and LSD-induced disruption of food-rewarded FR-4 bar pressing in the rat. In control and drug-pretreatment bar pressing sessions, designated groups $(N=6-12)$ received fixed doses of DMT $(3.2 \mathrm{mg} / \mathrm{kg})$ or LSD $(0.1 \mathrm{mg} / \mathrm{kg})$ with each rat serving as its own control. Graph points represent the mean duration (min \pm SE) of FR-4 bar pressing disruption, with solid lines $(\mathrm{O}-\mathrm{O})$ representing control groups and broken lines $(-\bullet)$ representing corresponding Lilly $127623(0.0032-$ $0.32 \mathrm{mg} / \mathrm{kg})$ and FK $33-824(0.0001-0.01 \mathrm{mg} / \mathrm{kg})$ pretreatment groups. For control pretreatment, groups received $0.9 \% \mathrm{NaCl} 15-20 \mathrm{~min}$ prior to DMT or LSD. In drug-pretreated groups predetermined behaviorally noneffective doses of LY 127623 and FK 33-824 were also administered at 15$20 \mathrm{~min}$ intervals prior to DMT or LSD. Significant antagonism to DMT-induced disruption of FR-4 bar pressing is shown with pretreatment doses of LY $127623(0.01-0.32 \mathrm{mg} / \mathrm{kg})$ and FK $33-824(0.001-0.01 \mathrm{mg} / \mathrm{kg})(t o p)$, whereas antagonism of LSD-induced behavioral effects is shown with LY $127623(0.10-0.32 \mathrm{mg} / \mathrm{kg})$ and FK $33-824(0.00032-0.0032 \mathrm{mg} / \mathrm{kg})$ pretreatment (bottom). Statistical significance of drug effects for control and corresponding pretreatment groups were calculated using two-tailed paired-comparison Student's t-tests in which the following symbols apply: ${ }^{*} P<0.05 ;{ }^{* *} P<0.01 ;{ }^{* *} P<0.001$. Numbers enclosed by parentheses represent the number of animals in designated groups. All injections were administered IP 
induced behavioral effects is shown with doses of LY 127623 $(0.10-0.32 \mathrm{mg} / \mathrm{kg})$ and FK $33-824(0.00032-0.0032 \mathrm{mg} /$ $\mathrm{kg}$ ). Although no differences from the DMT-induced effect were observed with pretreatment doses of $0.0032 \mathrm{mg} / \mathrm{kg} \mathrm{LY}$

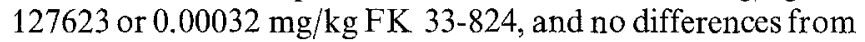
the LSD-induced effect were observed with $0.032 \mathrm{mg} / \mathrm{kg} \mathrm{LY}$ 127623 or $0.0001 \mathrm{mg} / \mathrm{kg}$ and $0.01 \mathrm{mg} / \mathrm{kg}$ FK $33-824$, it should be noted that typical gross behavioral effects characteristically observed with DMT or LSD were minimal or absent for the duration of induced disruption of FR-4 bar pressing. The data indicate LY 127623 as the more effective antagonist for DMT $(3.2 \mathrm{mg} / \mathrm{kg})$ and FK $33-824$ as the more effective LSD $(0.1 \mathrm{mg} / \mathrm{kg})$ antagonist.

\section{Discussion}

The present study demonstrates complex interactions between the synthetic metenkephalin opioid peptide analogs LY 127623 and FK 33-824 and the indole hallucinogens DMT and LSD. The dramatic antagonistic dose-dependent effects of the opioid peptides reported parallel the previous findings that the opioid agonists morphine and methadone antagonized disruption of FR-4 bar pressing induced by DMT and LSD, whereas the opioid antagonists naloxone and naltrexone potentiated the effects of DMT and LSD (Ruffing and Domino 1979, 1981).

Evidence implicating endogenous ligands and opioid receptors in the pathogenesis of various psychiatric illnesses has been reported by numerous investigators (Usdin et al. 1979; Olson et al. 1981; Gacel et al. 1981). As a model for psychosis, DMT and LSD-25 were used because they induce and mimic various aspects of psychotic behavior (Stoff et al. 1978; Jenner et al. 1980; Shulgin 1981). While DMT has been identified as an endogenous substance (Smythies et al. 1979), which can be synthesized from tryptamine in various tissues of humans and animals (Saavedra et al. 1973), significant differences in the amount of DMT excreted by psychotic and normal individuals have also been demonstrated (Erdelyi et al. 1979; Murray et al. 1979). Similarly, LSD-displacing factors (LDF) have been reported in unmedicated psychotic patients (Mehl et al. 1977) while, in rat brain endogenous ligands for two distinct LSD-serotonin receptors have recently been demonstrated (Peroutka et al. 1981).

It has been reported that DMT and LSD, while sharing similar hallucinogenic properties, show differences in the extent of dopaminergic and serotonergic involvement and activity (Glennon et al. 1980; Glennon and Rosecrans 1981; Nichols 1981). Prominent among LSD pharmacological and biochemical effects is a dual ability both to mimic and to block serotonin (5-HT) in the brain (Jacobs and Trulson 1981) and also to interact with dopamine (DA) and 5-HT receptors (Rosenfeld and Makman 1981). In addition, LSD has been shown to be a potent direct-acting DA agonist, whereas DMT is without effect (Cristoph et al. 1977; Von Hungen et al. 1975). Recently, binding studies have demonstrated that ${ }^{3} \mathrm{H}$-LSD can attach both to DA and 5-HT neurotransmitter sites, including spiroperidol-sensitive DA sites (Nielsen et al. 1980; Peroutka et al. 1981). The reported DA agonist activity is unique for LSD since other hallucinogens, like DMT, mescaline, and psilocybin have not demonstrated similar dopaminergic agonist actions (Burt et al. 1976; Jacobs and Trulson 1979, 1981; Trulson et al. 1981). The synergistic effect of an increase in the dopaminergic activity combined with a decrease in serotonergic activity may be a major factor in hallucinogenic drug potency, with the DA agonist activity modulating the magnitude of drug response.

Although DMT and LSD similarly decrease 5-HT turnover, only LSD has been shown to increase brain norepinephrine (NE) turnover and also alter the response of both 5-HTand catecholamine-stimulated adenylate cyclase, whereas DMT alters only the catecholamine-stimulated response (Ahn and Makman 1979). Interestingly, morphine-like opioids have been shown to inhibit stimulated adenylate cyclase activity (Terenius and Wahlstrom 1978).

The relationship of opioid peptides and synthetic analogs in psychological homeostasis is becoming increasingly important in view of their behavioral effects and high specificity of endorphin actions on brain functions (Frederickson et al. 1980; Fuxe et al. 1980; Verebey 1981). The existence of multiple neurotransmitters and opioid receptors has been clearly documented, indicating important variations in the molecular mechanism of action (Morley 1980; Beddell et al. 1980; Martin 1981).

The data obtained in these investigations substantiate important interactions of indole hallucinogens with opioids in the rat and strengthen the evidence for involvement of endogenous opioids in the pathogenesis of psychoses. The dramatic dose-dependent hallucinogen antagonistic effects of LY 127623 and FK 33-824 are especially significant and parallel previous findings involving interactions of morphine and methadone with DMT and LSD. These findings suggest that opioid agonists and related opioid-like peptides antagonize the effects of DMT and LSD by a specific and selective opioid agonist action. It would be of interest to extend these findings using various behavioral paradigms to examine effects of chronic pretreatment of opioid agonists and related peptides, and possible effectiveness of opioid antagonists to reverse the antagonistic effects of opioid agonists on hallucinogen-induced behavior.

\section{References}

Ahn HS, Makman MH (1979) Interaction of LSD and other hallucinogens with dopamine-sensitive adenylate cyclase in primate brain: Regional differences. Brain Res 162:77-88

Anokhina IP (1982) Several aspects of the interactions of the dopamine and opiate systems in schizophrenia. Vestn Akad Med Nauk USSR $1: 37-40$

Barchas JD, Berger PA, Watson SJ, Akil H, Li CH (1980) Opioid agonists and antagonists in schizophrenia. Adv Biochem Psychopharmacol 22:447-453

Beddell CR, Phil D, Lowe LA, Chem C, Wilkinson S (1980) Endogenous opioid peptides: The enkephalins and endorphins. In: Ellis GP, West GB (eds) Progress in medicinal chemistry, vol 17. Elsevier-North Holland Biomedical,pp $1-39$

Burt DR, Creese I, Snyder SH (1976) Binding interactions of lysergic acid diethylamide and related agents with dopamine receptors in the brain. Mol Pharmacol 12:631-663

Cristoph GR, Kuhn DM, Jacobs BL (1977) Electrophysiological evidence for a dopaminergic action of LSD: Depression of unit activity in the substantia nigra of the rat. Life Sci 21:1585-1590

Domino EF, Ruffing DM (1982) Evidence for opioids as partial antagonists of indole hallucinogens. Psychopharmacol Bull 18:175-179

Erdelyi E, Elliott GR, Wyatt RJ, Barchas JD (1979) S-Adenosylmethionine-dependent $\mathrm{N}$-methyltransferase activity in autopsied brain parts of schizophrenies and controls. Am J Psychiatry $135: 725-728$

Ferster CB, Skinner BF (1957) Schedules of reinforcement. Appleton Century Crofts, New York 
Frederickson RCA, Smithwick EL, Henry DP (1980) Opioid peptides as brain neurotransmitters with therapeutic potential: Basic and clinical studies. In: Marsan CA, Traczyk WZ (eds) Neuropeptides and neural transmission. Raven, New York, pp 227-235

Fuxe K, Andersson K, Locatelli V, Agati LF, Mutt V, Eneroth P (1980) Effect of neuroactive drugs and neuropeptides on the hypothalamic catecholamine nerve terminal systems and on neuroendocrine functions. In : Miller R (ed) Neuroactive drugs in endocrinology. Elsevier-North Holland, Amsterdam, pp 149-166

Gacel G, Fournic-Zaluski MC, Fellion E, Roques BP (1981) Evidence of the preferential involvement of $\mu$ receptors in analgesia using enkephalins highly selective for peripheral $\mu$ and $\delta$ receptors. J Med Chem 24:1119-1124

Gesellchen PD, Zimmerman DM (1981) Analgesics (peripheral and central), endogenous opioids and their receptors, In: McDermed W (ed) Annual reports in medicinal chemistry, vol 16. Academic, New York, pp 41-49

Glennon RA, Rosecrans JA (1981) Speculations on the mechanism of action of indolealkylamines. Neurosci Biobehav Rev 5:197-207

Glennon RA, Liebowitz SM, Anderson III GM (1980) Serotonin receptor affinities of psychoactive phenalkylamine analogues. J Med Chem 23:294-299

Jacobs BL, Truison ME (1979) Mechanism of action of LSD. Am Sci $67: 396-400$

Jacobs BL, Trulson ME (1981) An animal behavior model for decreased central serotonergic function. Adv Exp Med Biology 133:657-680

Jenner P, Marsden CD, Thanki CM (1980) Behavioral changes induced by N,N-dimethyltryptamine in rodents. Br J Pharmacol 69:69-80

Martin WR (1981) Multiple opioid receptors. Life Sci 28:1547-1554

Marx JL (1981) Brain opiates in mental illness. Science 214:1013-1015

Mehl E, Ruther E, Redmann J (1977) Endogenous ligands of a putative LSD-serotonin receptor in the cerebrospinal fluid: Higher level of LSD-displacing factors (LDF) in unmedicated psychotic patients. Psychopharmacology 54:9-16

Morley JS (1980) Structure-activity relationships of enkephalin-like peptides. Annu Rev Pharmacol Toxicol 20:81-110

Murray RM, Oon MCH, Rodnight R, Birley JLT, Smith BMA (1979) Increased excretion of dimethyltryptamine and certain features of psychosis. Arch Gen Psychiatry 36:644-649

Nichols DE (1981) Structure-activity relationships of phenethylamine hallucinogens. J Pharm Sci 70:839-849

Nielsen EB, Nielsen M, Ellison G, Braestrup C (1980) Decreased spiroperidol and LSD binding after continuous amphetamine. Eur J Pharmacol 66:149-154

Olson GA, Olson RD, Kastin AJ, Coy DH (1981) Endogenous opiates: 1980. Peptides 2:349-369

Peroutka SJ, Lebovitz RM, Snyder SH (1981) Two distinct central serotonin receptors with different physiological functions. Science $212: 827-829$

van Praag HM, Verhoeven WMA (1980) Neuropeptides: A new dimension in biological psychiatry. In: Usdin E, Sourkes TL,
Youdim MBH (eds) Enzymes and neurotransmitters in mental disease. Wiley, New York, pp 1-34

Rosenfeld MR, Makman MH (1981) The interaction of lisuride, an ergot derivative with serotonergic and dopaminergic receptors in rabbit brain. J Pharmacol Exp Ther 216:526-531

Ruffing DM, Domino EF (1979) Naloxone enhancement of DMT- and LSD-25-induced suppression of food-rewarded bar pressing behavior in the rat. Psychopharmacology 62:207-210

Ruffing DM, Domino EF (1981) Effects of selected opioid agonists and antagonists on DMT- and LSD-25-induced disruption of foodrewarded bar pressing behavior in the rat. Psychopharmacology $75: 226-230$

Saavedra JM, Coyle JT, Axelrod J (1973). A specific and sensitive enzymatic assay for tryptamine in tissues. J Pharmacol Exp Ther $182: 363-369$

Shulgin AT (1981) Hallucinogens. In: Wolff ME (ed) Burger's medicinal chemistry, part 3. Wiley, New York, pp 1109-1137

Smythies JR, Morin RD, Brown GB (1979) Identification of dimethyltryptamine and $\mathrm{O}$-methylbufotenin in human cerebrospinal fluid by combined gas chromatography-mass spectrometry. Biol Psychiatry $14: 549-556$

Snedecor GW, Cochran WG (1967) Statistical methods. Iowa State University Press, Ames, Iowa

Stoff DM, Gillin JC, Wyatt RJ (1978) Animal models of drug-induced hallucinations. In: Stillman RC, Willette RE (eds) The psychopharmacology of hallucinogens. Pergamon, New York, pp 259-267

Szara S (1982) Opiate receptors and endogenous opiates: Panorama of opiate research. Prog Neuropsychopharmacol Biol Psychiatry $6: 3-15$

Terenius L, Wahlstrom A (1978) Physiological and clinical relevance of endorphins. In: Hughes $\mathbf{J}$ (ed) Centrally acting peptides. University Park, Baltimore, pp 161-178

Trulson ME, Heym J, Jacobs BL (1981) Dissociations between the effects of hallucinogenic drugs on behavior and raphe unit activity in freely moving cats. Brain Res 215:275-293

Usdin E, Bunney WE, Kline NS (1979) Endorphins in mental health research. Oxford University Press, New York

Van Ree JM, deWied D (1981) Behavioral effects of beta-endorphin fragments. In: Rees LH, van Wimersma-Griedanus T (eds) Frontiers of hormone research, vol 8. Karger, Zurich, pp 178-192

Verebey K (1981) Opioids and psychological disorders. Adv Alcohol Substance Abuse 1:101-123

Von Hungen K, Roberts S, Hill DF (1975) Interactions between lysergic acid diethylamide and dopamine-sensitive adenylate cyclase systems in rat brain. Brain Res $94: 57-66$

Wenger GR (1980) Cumulative dose-response curves in behavioral pharmacology. Pharmacol Biochem Behav 4:601-603

deWied D (1980) Neuropeptides and psychopathology. Endeavour $4: 154-159$

Received September 23, 1982; Final version January 31, 1983 